

\section{Sumário}

I. Crônicas do Direito Internacional ...............................................1

REPARAÇÃo DE VÍTIMAS À LUZ DE UM TRATAdo SOBRE EMPRESAS E DIREITOS HUMANOS ............ 3 Ana Cláudia Ruy Cardia

Consumer Social Responsibility as a Requirement for Corporate Social ResponsibiliTY

Nitish Monebhurrun

Crisis in Venezuela: The Brazilian response to the massive flow of Venezuelans in

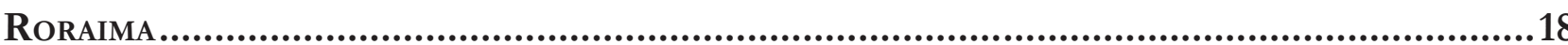

Jacqueline Salmen Raffoul

II. Dossiê EsPecial: Business and Human Rights.........................................23

Some remarks on the third sessions of the Business and Human Rights Treaty Pro-

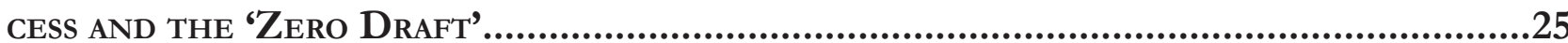

Humberto Cantú Rivera

The United Nations guiding principles on business and human Rights, the State

DUTY TO PROTECT HUMAN RIGHTS AND THE STATE-BUSINESS NEXUS.

Mihaela Maria Barnes

HARdening SOFT LAW: ARE THE EMERging Corporate SOCIAL DisClOSURE LAWS CAPABLE OF GENERATING SUBSTANTIVE COMPLIANCE WITH HUMAN RIGHTS?

Justine Nolan

Del Documento de Elementos al Draft 0: apuntes jurídicos respecto del posible CONTENIDO DEL PROYECTO DE INSTRUMENTO VINCULANTE SOBRE EMPRESAS TRANSNACIONALES

Y OTRAS EMPRESAS CON RESPECTO A LOS DERECHOS HUMANOS

Adoración Guamán 
ACCESS TO REMEDIES AND THE EMERGING ETHICAL DILEMMAS: CHANGING CONTOURS WITHIN THE BUSINESS-HUMAN RIGHTS DEBATE

Justin Jos

LA RESPONSABILIDAD PENAL DE LAS EMPRESAS POR GRAVES VIOLACIONES DE DERECHOS HUMANOS: PRÁCTICA ACTUAL Y DESAFÍOS FUTUROS 130

Daniel Iglesias Márquez

THE ENVIRONMENTAL LAW DIMENSIONS OF AN INTERNATIONAL BINDING TREATY ON BUSINESS AND HUMAN RIGHTS

Juan Gabriel Auz Vaca

Los Objetivos de Desarrollo Sostenible en Europa y su Intersección con el Marco de los Negocios y los Derechos Humanos

Paolo Davide Farah

HumAN RIGHTS AND MARKET ACCESS 203

Danielle Mendes Thame Denny

BusinesS AND HUMAN RIGHTS IN BRAZIL: EXPLORING HUMAN RIGHTS DUE DILIGENCE AND OPERATIONAL-LEVEL GRIEVANCE MECHANiSMS IN THE CASE OF KinRoss PARACATU Gold Mine...222 Mariana Aparecida Vilmondes Türke

Human Rights and eXtractive industries in Latin America: What Responsibility of CORPORATIONS AND THEIR STATES OF ORIGIN FOR HUMAN RIGHTS VIOLATIONS IN THE INTER-American Human Rights System?.

Alberto do Amaral Junior e Viviana Palacio Revello

MultinaCiOnAIS FAST FASHION E DIREITOS HUMANOS: EM BUSCA DE NOVOS PADRÕES DE RESPONSABILIZAÇÃO 255

Laura Germano Matos e João Luis Nogueira Matias

III. Artigos sobre outros temas

EFFICIENCY AND EFFICACY OF PUBLIC FOOD PROCUREMENT FROM FAMILY FARMERS FOR SCHOOL FEEDING IN BRAZIL. 271

Rozane Márcia Triches 
A relaÇão ENTRE O GRAU de INTEGRaÇÃo ECONÔMiCA E O SISTEMA DE SOLUÇÃo DE CONTROvÉRSIAS: UM ESTUdo COMPARATIVO ENTRE A UNIÃo EURopeia E O MERCOSUl.....................286

Luciane Klein Vieira e Elisa Arruda

THE RIGHTS TO MEMORY AND TRUTH IN THE INTER-AMERICAN PARADIGMS OF TRANSITIONAL JUSTICE: THE CASES OF BRAZIL AND CHILE 308

Bruno Galindo

Juliana Passos de Castro

A margem nacional de apreciação na Corte Interamericana de Direitos Humanos.325 Gilberto Schäfer, José Eduardo Aidikaitis Previdellie e Jesus Tupã Silveira Gomes

Novos Direitos FUNDAMENTAIS NO ÂMBITo DA UNASUL: ANÁLISE DAS AGENDAS DE Brasil E VENEZUELA À LUZ DO DIREITO À PAZ.

Pedro Pulzatto Peruzzo e Arthur Ciciliati Spada

A atuação do Grupo Mercado Comum frente À Criminalidade organizada transnacio-

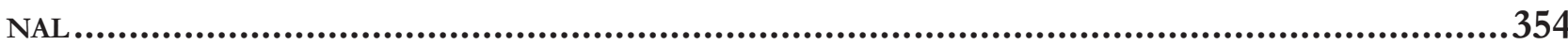

Sabrina Cunha Kesikowski, Luis Alexandre Carta Winter e Eduardo Biacchi Gomes

COUNTER-TERRORISM LEGISLATION AND TERRORIST ATTACKS: DOES HUMAN RIGHTS HAVE SPACE?

Heloisa Tenello Bretas e Daniel Damásio Borges

Territórios da ViolênCia de GÊNERo: NORMATIVA INTERNACIONAL E os Casos "CAMpo AlGodoeiro” (MÉXICO) - “Morro do Garrote” (BrasiL)

Eugênia Nogueira do Rêgo Monteiro Villa e Bruno Amaral Machado

O USO DE MECANISMOS INFORMAIS DE GOVERNANÇA GLOBAL E SUA APLICABILIDADE NAS LICITAÇÕES PÚBLICAS BRASILEIRAS.

Fabiano de Figueiredo Araujo e Paulo Afonso Cavichioli Carmona

Autonomia INSTITUCIONAL DA IGREJA CATÓliCA E A INGERÊNCIA INDEVIDA DO ESTADO BRASILEIRo POR EVENTUAIS Ilícitos CANÔNicos: ANÁlise do CASO de Formosa-GO, À luz do TraTADo Brasil-Santa SÉ de 2010 
A MORE TARGETED APPROACH TO FOREIGN DIRECT INVESTMENT: THE ESTABLISHMENT OF SCREENING SYSTEMS ON NATIONAL SECURITY GROUNDS

Carlos Esplugues Mota

IV. RESENHAS 467

Direito Internacional em Perspectiva Transcivilizacional de Yasuaki Onuma........469 Arthur Roberto Capella Giannattasio

Resenha do livro Space, Global Life: The Everyday Operation of International LaW and Development, de Luis Eslava .473

Matheus Gobbato Leichtweis

QUEM TEM MEDO DO PÓS-COLONIAL NO DIREITO INTERNACIONAL? UMA RESENHA DE "DECOLONISING INTERNATIONAL LAW: DEVELOPMENT, ECONOMIC GROWTH AND THE POLITICS OF UNIVERSAlity" de Sundhya Pahuja

Gabriel Antonio Silveira Mantelli

Direitos humanos COMO UM NOVO PROJETO PARA O Direito INTERNACIONAL? Notas sobre The Last Utopia, de Samuel Moyn .490 João Roriz 


\title{
Human rights and extractive industries in Latin America: what responsibility of corporations and their States of origin for human rights violations in the Inter-American Human Rights System?*
}

\author{
Derechos humanos e industrias extractivas \\ en América Latina: ¿cuál es la responsabilidad \\ de las empresas y sus Estados de origen por \\ violaciones de derechos humanos ante el \\ Sistema Interamericano de Derechos Humanos?
}

\author{
Alberto do Amaral Junior** \\ Viviana Palacio Revello***
}

\footnotetext{
* Recebido em 15/06/2018

Aprovado em 01/08/2018
}

** Associate Professor of International Law of Faculty of Law at University of São Paulo, since 2001. Member of the Institute of Law and International Relations. Visiting Scholar at Yale Law School, 2003 and 2007. Founder member and former research director of the Institute of International Trade and Development. Founding member and Head of Orbis Centre for International Law and International Relations. Author, among oters, of the following books: International Trade and the Environment, Publisher Atlas, 2011, Course of Public International Law, third edition, Publisher Atlas, 2013, editor of the books to be published: WTO Dispute Settlement Body, from a developing country perspective, Springer, 2018, The Environmental Consumption, 2019. Email: aamaralj@ uol.com.br.

*** Lawyer at the Secretary of Education of Medellin. Magister in International and Comparative Law (Universidade de São Paulo, Brazil), approved with honor and distinction. Attorney and Political Scientist (Universidad Pontificia Bolivariana, Colombia). Winner in 2012 of the "Best Memorial in Spanish - Representatives of the Victims" in the XVII InterAmerican Human Rights Moot Court Competition. Intern in 2014 at the Inter-American Commission on Human Rights, Group of the Court. Judge of the eliminatory and semifinal rounds in 2017 and 2016 of the XXII and XXI Inter-American Human Rights Moot Court Competition, and judge of written memorials in 2018 of this competition.

Email: vpalaciorevello@gmail.com.

\begin{abstract}
The second half of the twentieth century reached expansion of external trade, followed in some cases by improvement in democratic processes and living conditions. Nevertheless, the strong rise of economic globalization and trade among countries started to challenge the enjoyment of some human rights. Investment agreements redefine economic landscapes, but simultaneously some of them threaten civil and political rights, as well as economic, social and cultural rights. Before this situation, in the field of human rights and extractive industries in Latin America, the issue related to responsibility of corporations and their States of origin for human rights violations in the inter-American human rights system arises. Inter-American standards and prospects on responsibility for human rights abuses committed by corporations operating in a third State are discussed in this paper. We concluded that even if international standards on this issue are still strengthening, positive developments can be arising.
\end{abstract}

Keywords: Global market. Human rights. Concessional agreements. Corporations. International responsibility of the State.

\section{Resumen}

La segunda mitad del siglo veinte trajo consigo la expansión del comercio, seguido en algunos casos de mejoramiento en los procesos democráticos y las condiciones de vida. Sin embargo, el auge de la globalización económica y el comercio entre países comenzó a desafiar el goce de algunos derechos humanos. A pesar de que los acuerdos de inversión redefinen perspectivas económicas, la ejecución de algunos de ellos amenaza el goce de los derechos civiles y políticos, así como de los derechos económicos, sociales 
y culturales. Ante esta situación, en materia de derechos humanos e industrias extractivas en América Latina, surge la cuestión de la responsabilidad de las empresas y sus Estados de origen por violaciones de derechos humanos ante el sistema interamericano de derechos humanos. En este artículo se discuten los estándares y perspectivas interamericanos sobre responsabilidad por violaciones de derechos humanos de empresas que operan en terceros países. Concluimos que a pesar de que los estándares internacionales en este tema aún están consolidándose, están surgiendo desarrollos positivos.

Palabras clave: Mercado global. Derechos humanos. Acuerdos de inversión. Empresas. Responsabilidad internacional del Estado.

\section{INTRODUCTION}

"The existence of a free market does not of
course eliminate the need for government. On the
contrary, government is essential both as a forum
for determining the 'rule of the game' and as an
umpire to interpret and enforce the rules decided
on."

Milton Friedman.

After two world wars, millions of deaths because of diseases, starvation, indiscriminate killings and tortures, the second half of the twentieth century arrived and ended with two relevant lessons. The first one is that countries economically isolated suffer from shortage and lags, and are lead to underdevelopment. The second one is that human rights recognition dignifies lives of societies, humanizing and civilizing the relationship between human beings and the State. Current Western world cannot live without a diversified global market and a set of human rights effectively recognized.

Global market and human rights became great advances of the last half of the twentieth century. They became, also, complementary. Trade and investment agreements, components of the global market, emerged as mechanisms to settle trading balances between the first-world countries and the others, and to contribute to sustainable development. Likewise, a set of human rights protected prerogatives in which market is based, such as the right to pursue a project of life and the freedom of labor. Economic liberalization to increase competitiveness and recognition of human dignity for all by virtue of their status as persons are not competing aims by themselves, on the contrary, at some point, one depends on the other.

Nevertheless, the States and international organizations are no longer the sole involved in global commitments. An intermingling of actors and interests is making both concepts switch their focus, although history has taught current Western world that it should not renounce to global market or to human rights guarantee. More specifically, some projects related to extractive industries in Latin America are being conducted in conditions of environmental damage, intimidation, death of social and communal leaders, police repression, house arrest and arbitrary detention, criminalization of social protest, forced or involuntary displacement, and militarization of the populations.

This paper begins by considering investment agreements in times of protection of human beings; continues by addressing responsibility of corporations and States of origin for human rights abuses in times of concessional agreements boom in Latin America; and concludes by discussing the inter-American standards and prospects on responsibility for human rights violations committed by corporations operating in a third State.

\section{INVESTMENT AGREEMENTS IN TIMES OF PROTECTION OF HUMAN BEINGS}

After decades of protectionism during the world wars, the second half of the twentieth century led to expansion of economic globalization followed, in numerous cases, by improvement in democratic processes and/or living conditions. As an example brought by the International Monetary Fund, most of the East Asia countries, which were among the poorest ones forty years ago, are currently prosperous and dynamic due to the implementation of liberalization policies. ${ }^{1}$ This section departs from considering the intermingling of actors and interests in the global scenario and concludes by questioning the forgetfulness of the State obligation to ensure the enjoyment of human rights when negotiating or executing investment agreements.

The Organization for Economic Co-Operation and

1 INTERNATIONAL MONETARY FUND. La globalización: ¿amenaza u oportunidad? Available in: <https://www.imf.org/external/np/exr/ib/2000/esl/041200s.htm>. 
Development (OECD), in a report titled Trading out of Poverty: How Aid for Trade Can Help says that trade is central to economic growth and poverty reduction, but "while low- and middle- income countries have made substantial progress in dismantling their trade barriers over the past two decades, this has not appeared to unleash sustained export growth in all of them."2 The reduction of poverty, one of the benefits that trade and investment agreements bring, does not appear to be received by some developing countries, nor by all social groups in the States. According to the OECD, "[r]ecent country case studies confirm that the link between export growth and poverty reduction has been mostly positive, but there are nonetheless some negative cases, indicating that other factors may be hindering the impact of trade or are much more important in determining the process of poverty reduction." 3

Economic politics are shaped by the interaction of multiple actors. Therefore, reaping the benefits that investment agreements could bring should consider divers agents and interests, which intermingle. There is in this point a concern that goes beyond the content of the law and that considers the form it is born and developed, looking at the behavior of engaged actors on the transnational practice. ${ }^{4}$ Timothy Shaw, Andrew Grant and Scarlett Cornelissen claim that

Regional development in the twenty-first century is as much a function of corporate strategies and informal sectors as endless inter-governmental negotiations and declarations. Private sectors and state priorities may or may not be compatible, but neither can be ignored ... hence, in the new century, regional development may be more advanced by corporate strategies rather than by state directives. ${ }^{5}$

As a consequence of performance of private sectors in the world trade, conclusion of trade and investment agreements promoting objectives of companies has

2 ORGANIZATION FOR ECONOMIC COOPERATION AND DEVELOPMENT. Trading out of poverty: how aid for trade can help. OECD Journal on Development, v. 10, n. 2, p. 7-41, 2010. p. 12. 3 ORGANIZATION FOR ECONOMIC COOPERATION AND DEVELOPMENT. Trading out of poverty: how aid for trade can help. OECD Journal on Development, v. 10, n. 2, p. 7-41, 2010. p. 14. 4 MANGE, Flávia Foz. As características do direito transnacional como metodologia: análise sob o enfoque dos aspectos processuais da arbitragem, Revista de Direito Internacional, v. 13, n. 3, p. 126-144, 2016. p. 130.

5 GRANT, Andrew. Introduction and overview: the study of new regionalism(s) at the start of the second decade of the twenty-first century. In: SHAW, Timothy; GRANT, Andrew; CORNELISSEN, Scarlet. The ashgate research companion to regionalisms. Surrey: Routledge, 2012. p. 16. proliferated. Corporations, national and transnational, are genuinely interested in the market structure, which channels the negotiation processes between the States and the content of several provisions in international treaties relating these matters. About the current relevance of market structure in trade negotiation processes, Kim Moonhawk argues that

$[\mathrm{A}] \mathrm{s}$ the structure of the international economy has evolved throughout the post-World War II era, states' focus has shifted away from market access -as defined by tariffs and other "at-the-border" measures- toward market structure. Market structure is shaped by the extent of competition within an industry and in an economy more broadly. It varies between perfect competition with a high level of competition and monopoly with no competition. $^{6}$

Concessional agreements in Latin American extractive industries are examples of that kind of competition. On the subject of competition on trade-related field, the assessment of Dani Rodrik in the sense that "we need smart globalization, not maximum globalization" "7 is true. Rodrik also claims that markets and governments are complements and not substitutes, and that markets work best not where the States are weaker, but where they are stronger, because the prosecution of aims such as the preservation of legitimacy of markets by protecting people from the risks and insecurities markets bring with them is required. ${ }^{8}$ The protection of people from these risks and insecurities is impacted by an intermingling of interests.

Sovereignty, governance and legitimacy concepts are challenged and rethought. As an example of this, Immanuel Wallerstein argues that

All states are theoretically sovereign, but strong
states find it far easier to "intervene" in the internal
affairs of weaker states than vice versa, and everyone
is aware of that. Strong states relate to weak states
by pressuring them to keep their frontiers open to
those flows of factors of production that are useful
and profitable to firms located in the strong states,
while resisting any demands for reciprocity in this
regard. In the debates on world trade, the United
States and the European Union are constantly
demanding that states in the rest of the world
open their frontiers to flows of manufactures and

6 MOONHAWK, Kim. Inspecting the termites: market structure and WTO's consideration process of PTAs. American Political Science Association, 2013. p. 7.

7 RODRIK, Dani. The globalization paradox. New York: W. W. Norton \& Company, 2011. p. 8.

8 RODRIK, Dani. The globalization paradox. New York: W. W. Norton \& Company, 2011. p. 8. 
services from them. They however quite strongly resist opening fully their own frontiers to flows of agricultural products or textiles that compete with their own products from states in peripheral zones. Strong states relate to weak states by pressuring them to install and keep in power persons whom the strong states find acceptable, and to join the strong states in placing pressures on other weak states to get them to conform to the policy needs of the strong states . . . Strong states relate to weak states by pressuring them to follow their lead in international arenas (treaties, international organizations). And while strong states may buy off the individual leaders of weak states, weak states as states buy the protection of strong states by arranging appropriate flows of capital. ${ }^{9}$

Saskia Sassen describes the current panorama as "the consolidation of a transnational economy that has its center of gravity in the North Atlantic system both in terms of the intensity and value of transactions, and in terms of the emerging system of rules and standards." ${ }^{10}$ And she continues, arguing that it results in "a mix of new strengthened forms of private authority and partly denationalized state authority, such as the instituting of private interests into state normativity." 11

Some believe that "global markets suffer from weak governance, and are therefore prone to instability, inefficiency, and weak popular legitimacy." 12 We argue that the weak popular legitimacy that global markets can eventually have is because human rights arguments are not raised when negotiating and/or executing trade and investment agreements. Collaboration between public and private sectors to manage global affairs is noticeable; the point is that aspects that confer legitimacy to the market such as the respect for human rights are constantly left behind. In this regard, it seems relevant the assessment of Friedrich Hayek in the sense that

[t]here are, in the last resort, no economic ends [and] the economic efforts of the individuals as well as the services which the market order renders to them, consist in an allocation of means for the competing ultimate purposes which are always non-

9 WALLERSTEIN, Immanuel. World systems analysis. London: Duke University Press, 2004. p. 55.

10 SASSEN, Saskia. The State and globalization. In: HALL, Rodney Bruce; BIERSTEKER, Thomas J. (Ed.) The emergence of private authority in global governance. Cambridge: Cambridge University Press, 2002. p. 98.

11 SASSEN, Saskia. The State and globalization. In: HALL, Rodney Bruce; BIERSTEKER, Thomas J. (Ed.) The emergence of private authority in global governance. Cambridge: Cambridge University Press, 2002. p. 106.

12 RODRIK, Dani. The globalization paradox. New York: W. W. Norton \& Company, 2011. p. 6. economic. $^{13}$

\section{RESPONSIBILITY OF CORPORATIONS AND STATES OF ORIGIN FOR HUMAN RIGHTS ABUSES IN TIMES OF CONCESSIONAL AGREEMENTS BOOM INLATIN AMERICA}

Investment agreements redefine the economic landscape of a country, but simultaneously some of them threaten the right to food, collective rights of specially protected subjects, labor rights and the right to health. Investment agreements are supposed to be a mechanism to settle trading balances between the first-world countries and the others, and to foster sustainable development; however, some of them are benefiting transnational corporations at the expense of the enjoyment of human rights in some areas of the world. Indeed, the companies whose transnational activities allegedly or demonstrably have adverse socio-environmental impacts are potentially protected by a wide array of investment protection agreements. ${ }^{14}$ Human rights continuously yield to concessions made by the States with a view to attract investors. Problematic issues are the agreements that also involve countries indicted of serious human rights violations.

In terms of responsibility of corporations and the States of origin for human rights abuses, one of the most current cases is that one related to violations committed by some enterprises incorporated under the laws of Canada acting in the field of extractive industries in Latin America. This statement is sustained in the analysis of 24 cases located in Argentina, Brazil, Chile, Colombia, El Salvador, Guatemala, Honduras, Mexico, Panama and Peru, set out in the framework for the $149^{\text {th }}$ Ordinary Period of Sessions of the Inter-American Commission on Human Rights (IACHR) in 2013, in a public regional hearing about the situation of human rights of the affected people due to mining activities in the Americas and the responsibility of the host countries, States of origin and companies. ${ }^{15}$

13 HAYEK, Friedrich A. Law, legislation, and liberty: a new statement of the liberal principles of justice and political economy. London: Routledge, 1976. p. 320.

14 MONEBHURRUN, Nitish. Mapping the duties of private companies in international investment law. Revista de Direito Internacional, Brasília, v. 14, n. 2, p. 50-71, 2017. p. 53.

15 INTER-AMERICAN COMMISSION ON HUMAN RIGHTS. Audiencia: Situación de derechos humanos de las personas 
According to the information provided by the Petitioners, $75 \%$ of the world's mining companies are registered in Canada, and about two-thirds of this percentage operates in Latin America. A specific number of these projects are being executed in conditions of environmental damage, intimidation, death of social and communal leaders, police repression, house arrest and arbitrary detention, criminalization of social protest, forced or involuntary displacement, and militarization of the populations. ${ }^{16}$ The contamination of the gorges Tibia and Cuajiniquil in Honduras in 2008 as a consequence of infiltration of the acid drainage coming from the activity of Entre Mares Company and the prosecution in 2012 of 200 people in Argentina for protesting against the project Alumbrera were cited as examples. ${ }^{17}$

In this respect, regarding environmental damage caused by the activity of corporations, it should be taken into account that an environment of sufficient quality has become an inherent condition for the full respect of some human rights such as the right to life, health, private and family life, food, an adequate living standard, right to property and cultural rights. In this sense, the Protocol of San Salvador provides in Article 11 that "[e]veryone shall have the right to live in a healthy environment."

afectadas por la minería en las Américas y responsabilidad de los Estados huéspedes y de origen de las empresas mineras. Available in: $<$ https: / $/$ www.youtube.com $/$ watch?v $=6 \mathrm{M} 7 \mathrm{gX} 1 \mathrm{snfCQ}>$.

16 Precautionary measures on the specific subject of the impact on Canadian mining activities in Latin America are still pending. Nevertheless, for further information on the context in which human rights abuses related to the execution of megaprojects are committed, see, as examples, the following precautionary measures granted by the IACHR: PM 50/14 - Campesino Leaders of Bajo Aguán (Honduras), issued considering killings, disappearances, kidnappings, torture, threats, violent evictions, persecution and accusations to which peasant farmers were subjected for the alleged purpose of forcing them to sell their lands; PM 140/14 - Yomaira Mendoza and others (Colombia), granted on the basis of the serious risk of their rights to life and personal integrity; and PM 195/13 - Leaders and Human Rights Defenders from the Community of Nueva Esperanza and the Regional Council of the Florida Sector (Honduras), issued considering the serious risk of their lives and physical integrity as a consequence of their work to oppose various mining projects executed in the area.

17 INTER-AMERICAN COMMISSION ON HUMAN RIGHTS. Audiencia: Situación de derechos humanos de las personas afectadas por la minería en las Américas y responsabilidad de los Estados huéspedes y de origen de las empresas mineras. Available in: $<$ https: / $/$ www.youtube.com/watch?v $=6 \mathrm{M} 7 \mathrm{gX} 1 \mathrm{snfCQ}>$.

18 ORGANIZATION OF AMERICAN STATES. Additional protocol to the American Convention on Human Rights in the area of economic, social and cultural rights. Available in: <http:/ / www.cidh.org/Basicos/ Portugues/e.Protocolo_de_San_Salvador.htm>. ned taking into account that the well-being of each individual or community, particularly indigenous peoples, has a high correlation to the surrounding level of environmental quality.

The cases reported in the public hearing mentioned above were endorsed in a new public hearing conducted on October $28^{\text {th }}, 2014$ before the IACHR about the impact on Canadian mining activities in Latin America. ${ }^{19}$ According to the information provided by the Petitioners, companies developing mining projects are impacting social, cultural, environmental, and economic well-being of communities, particularly indigenous peoples, violating systematically their human rights, despite their status as specially protected subjects according to the international human rights law. ${ }^{20}$ Similar acts of intimidation and death of social and communal leaders were denounced in a new case in Mexico. ${ }^{21}$

Those concerns were put on the table once again. Within the framework for the $154^{\text {th }}$ Ordinary Period of Sessions of the IACHR, in a public regional hearing about companies, human rights and prior consultation in the Americas, the Petitioners emphasized the importance of the companies as fundamental actors within the society, the relevance to achieve real development through their actions, and that human rights are not an obstacle for the economic development, but a condition to obtain it. ${ }^{22}$ The use of the concept of territory

19 INTER-AMERICAN COMMISSION ON HUMAN RIGHTS. Audiencia: Impacto de las empresas mineras canadienses sobre los derechos humanos en América Latina. Available in: $<$ https://www.youtube.com/watch?v $=$ OWYue8FP9ZY\&feature $=$ you tu.be $>$.

20 Several of the human rights abuses regarding the indigenous communities begin by irregularities in the ancestral land acquisition processes. We cannot avoid taking into account that guaranteeing the collective right to property of indigenous communities is a first step to ensure their social, cultural, environmental and economic well-being, and also a first step to protect them from illegitimate or arbitrary appropriation or occupation and from deterioration of its natural resources. For further information about human rights abuses committed in the framework of megaprojects execution, see resonated cases before the IACHR such as PM 382/10 - Indigenous Communities of the Xingu River Basin (Brazil), granted considering that the lives and personal integrity of the beneficiaries were at risk due to the impact of the construction of Belo Monte hydroelectric power station.

21 INTER-AMERICAN COMMISSION ON HUMAN RIGHTS. Audiencia: impacto de las empresas mineras canadienses sobre los derechos humanos en América Latina. Available in: $<$ https://www.youtube.com/watch? $\mathrm{v}=$ OWYue8FP9ZY\&feature $=$ you tu.be $>$.

22 INTER-AMERICAN COMMISSION ON HUMAN RIGHTS. Audiencia: empresas, derechos humanos y consulta 
as a barrier to guarantee the rights of the victims was queried once more. ${ }^{23}$ It is in this context that companies are being increasingly encouraged, especially by the civil society, by the national legislation of some States and by some international instruments, to adopt responsible behaviors, mainly when their activities have cross-border effects. ${ }^{24}$

Before this situation, it remains the question about the effectiveness of Article 36 of the Organization of American States (OAS) Charter regarding the activity of transnational enterprises in the territory of Member States, in accordance to which

\begin{abstract}
$[\mathrm{t}]$ ransnational enterprises and foreign private investment shall be subject to the legislation of the host countries and to the jurisdiction of their competent courts and to the international treaties and agreements to which said countries are parties, and should conform to the development policies of the recipient countries. ${ }^{25}$
\end{abstract}

Repeatedly, the exclusive interests of companies are presented as national interests. Notwithstanding, we argue that private interests or agendas cannot be superimposed to well-being of communities when both collide, primarily because trade and investment agreements are based on the logic of being economic and social development tools for the societies they serve. In this regard, the Office of the United Nations High Commissioner for Human Rights (OHCHR) affirms that "[w]ithout the introduction of appropriate safeguards and transitional measures, trade rules and policies could have adverse effects on the right to food, worker's rights and other rights of small farmers and the rural poor." ${ }^{26}$

Thus, would it be possible to apply extraterritorially the concept of acquiescence by the States regarding human rights violations committed by companies in-

previa en América. Available in: <https://www.youtube.com/ watch? ${ }_{\mathrm{v}}={ }_{\mathrm{wF}} \mathrm{Fc} 7 \mathrm{ccS} 7 \mathrm{Mw}>$.

23 INTER-AMERICAN COMMISSION ON HUMAN RIGHTS. Audiencia: empresas, derechos humanos y consulta previa en América. Available in: <https://www.youtube.com/ watch? $\mathrm{v}=\mathrm{wFqc} 7 \mathrm{ccS} 7 \mathrm{Mw}>$.

24 ANDRADE, Priscila Pereira de. A emergencia do direito transnacional ambiental, Revista de Direito Internacional, v. 13, n. 3, p. 18-28, 2016. p. 19.

25 ORGANIZATION OF AMERICAN STATES. Charter of the organization of American States. Available in: <https://www.oas.org/ dil/port/tratados_A-41_Carta_da_Organiza $\% \mathrm{C} 3 \% \mathrm{~A} 7 \% \mathrm{C} 3 \% \mathrm{~A} 3 \mathrm{O}$ dos_Estados_Americanos.htm $>$.

26 HARRISON, James. Human rights and world trade agreements: using general exception clauses to protect human rights. New York: Office of the High Commissioner for Human Rights, 2005. p. 2. corporated under their jurisdiction? Currently, without the evidence of political or financial support, it appears defeasible. Prosecuting people for acts of corruption committed outside the territory is legally viable in some countries, why is not it still possible for human rights abuses when the State exercises authority over a person even if she is not a public servant? The problems exposed above could raise violence levels in regions traditionally affected by social inequality, high poverty and distrust of the justice system such as some Latin American countries, ${ }^{27}$ and even worse when the agreements involve countries indicted of gross human rights violations. The increase of violence restricts community development, and so remains in a vicious circle.

\section{INTER-AMERICAN STANDARDS AND PROSPECTS ON RESPONSIBILITY FOR HUMAN RIGHTS ABUSES COMMITTED BY CORPORATIONS OPERATING IN A THIRD STATE}

Some legal scholars assert that the authority of the law depends " $[\ldots]$ on its justice or at least its ability to secure justice." 28 In this regard, the notion of justice is currently entrenched in the protection of the human beings regardless their sex, race, religion, political opinion, language, national or social origin or other status. Few dare to dissent that in our current times, the recognition and guarantee of inherent rights of human beings because of their status as persons are a part of the general sense of justice. This section exposes the inter-American standards on responsibility for human rights violations committed by corporations operating in a third State and then presents a mechanism seeking to reconcile human rights imperatives with trade objectives: human rights considerations set out in arbitral awards. Various awards contain several references to the necessity of applying standards of treatment in a way that protects the so-called non-commercial values (i.e. values not pertaining to the protection of property but relating to the safeguard of other essential interests such as environment and human health). ${ }^{29}$

27 AYALA, Natalia. Derechos humanos y globalización: un análisis preliminar para América Latina. Desarrollo, Economía, Ecología y Equidad, p. 2-17, 2003. p. 13.

28 FINNIS, John. Natural law and natural rights. Oxford: Clarendon Press, 2001. p. 260.

29 ZARRA, Giovanni. Right to regulate, margin of appreciation 
First of all, States have the duty to respect human rights under all circumstances-except from situations in which there is a permission to restrict certain rights-but they do not have the legal duty to ensure or protect the human rights of people that live outside their territory or jurisdiction, as a general rule. Taking into consideration this situation, the extraterritorial responsibility of the home States of corporations involved in human rights violations-whether directly or through corporate policies that acquiesce in impairments caused by their subsidiaries in third countries-becomes an issue of current debate.

The State duty to respect and guarantee human rights is enshrined in some international treaties. The International Covenant on Civil and Political Rights, e. g., in Article 2(1) states that "[e]ach State Party [...] undertakes to respect and to ensure to all individuals within its territory and subject to its jurisdiction the rights recognized in the present Covenant, without distinction of any kind." ${ }^{30}$ The American Convention on Human Rights, for its part, in Article 1(1) provides that

[t]he States Parties [...] undertake to respect the rights and freedoms recognized herein and to ensure to all persons subject to their jurisdiction the free and full exercise of those rights and freedoms, without any discrimination. ${ }^{31}$

At a very first moment, the duties of the State were defined as abstaining from violating fundamental freedoms, but this view changed progressively. Currently, the State duties are understood not only as obligations to respect, but also to protect and ensure civil and political rights, as well as economic, social and cultural rights by means of positive measures that give effectiveness to human rights. Under these conditions, in the inter-American human rights system, in accordance with the American Convention on Human Rights and the American Declaration of the Rights and Duties of Man, the States are obliged to take positive measures to ensure human rights, including in relation to their actual or potential violation by private parties.

and proportionality: current Status in investment arbitration in light of Philip Morris v. Uruguay, Revista de Direito Internacional, v. 14, n. 2, p. 95-120, 2017. p. 96.

30 UNITED NATIONS. International covenant on civil and political rights. Available in: <https://www.ohchr.org/en/professionalinterest/pages/ccpr.aspx $>$.

31 ORGANIZATION OF AMERICAN STATES. American convention on human rights. Available in: < https://www.cidh.oas.org/basicos/portugues/c.convencao_americana.htm>.
The IACHR has addressed State responsibility for acts committed abroad when the acts or omissions have an impact outside the territory of the respondent State. For instance, in the inter-State petition PI-02 Franklin Guillermo Aisalla Molina (Ecuador) v. Colombia, Report on Admissibility No. 112/10, it was established that

[T] he States not only may be held internationally responsible for the acts and omissions imputable to them within their territory but also for those acts and omissions committed wherever they exercise jurisdiction [...]. Under Inter-American human rights law, each American State is obligated therefore to respect the rights of all persons within its territory and of those present in the territory of another state but subject to the control of its agents. ${ }^{32}$

Similarly, the IACHR has also addressed State responsibility for acts committed in another country when the alleged violator of an international duty is under the authority or effective control of the respondent State. In this sense, in the Decision on Request for Precautionary Measures of the Detainees at Guantanamo Bay issued in March 2002 and the inter-State petition PI-02 Franklin Guillermo Aisalla Molina (Ecuador) v. Colombia, the IACHR stated that both the American Convention on Human Rights and the American Declaration of the Rights and Duties of Man have extraterritorial application with respect to acts of military occupation, military action or detention. ${ }^{33}$

That said, although the OAS Charter defines that transnational corporations are subject to the laws and jurisdiction of the courts of the countries in which they operate, no decisions have been issued establishing criteria for attributing State responsibility for the conduct of corporations operating in third countries. Under current inter-American standards, the acts of corporations abroad are not considered directly attributable to their State of origin, unless those companies perform government functions with the support and cooperation of

32 INTER-AMERICAN COMMISSION ON HUMAN RIGHTS. Report on admissibility no. 112/10 Franklin Guillermo Aisalla Molina (Ecuador) v. Colombia (2010). \90-91. Available in: <www. cidh.org/annualrep/2010eng/EC-CO.PI-02ADM.EN.doc>.

33 INTER-AMERICAN COMMISSION ON HUMAN RIGHTS. Decision on request for precautionary measures of the detainees at Guantanamo Bay (2002). Available in: <http://www.oas. org/en/iachr/pdl/decisions/GuantanamoMC.asp\#MC25902>.; Report on INTER-AMERICAN COMMISSION ON HUMAN RIGHTS. Report on admissibility no. 112/10 Franklin Guillermo Aisalla Molina (Ecuador) v. Colombia (2010). Available in: <www.cidh.org/ annualrep/2010eng/EC-CO.PI-02ADM.EN.doc>. 
the State. Despite the increasing relevance of corporations in the global scenario, legal personality as subjects of international law has not been granted to them ${ }^{34}$ and the host States remain being responsible for human rights abuses committed, either by action, omission or acquiescence. In other words, in international law, the investor-company and its investment benefit from a consolidated legal bulwark to protect its activities but have, in international law, very few obligations vis-à-vis the host States and their population: there is a power relationship in disequilibrium with a hyper-protected corporate world on one side, and sometimes vulnerable communities on the other. ${ }^{35}$

Nevertheless, the standards developed on the obligation to respect, protect and guarantee rights in relation to the acts of private parties and decisions on extraterritorial liability issued by human rights bodies make it possible to rule out a merely territorial notion of jurisdiction. Some international courts have allowed for exceptions to the rule that private entities are distinct from the State when a government establishes a policy of absolute control over an industry, such as in the arbitral award of Philips Petroleum Co. Iran v. Islamic Republic of Iran et al. ${ }^{36}$ or when the corporation exercises official powers in conducting the activity for which it has been awarded a concession, such as in the Case of Ximenes-Lopes v. Brazil. ${ }^{37}$

The universal human rights system has urged that the States change laws or policies that result conducive to human rights abuses in the territory of third countries, for instance, in the Guiding Principles on Business and Human Rights, stating that "States should set out clearly the expectation that all business enterprises domiciled in their territory and/or jurisdiction respect buman rights throughout their operations. ${ }^{138}$ The Guiding Principles were favora-

34 A locus standi recognizing certain rights and obligations before the governments has been granted to corporations. This has been understood as a secondary or derived legal personality at the international level.

35 MONEBHURRUN, Nitish. Mapping the duties of private companies in international investment law. Revista de Direito Internacional, Brasília, v. 14, n. 2, p. 50-71, 2017. p. 53.

36 PHILIPS PETROLEUM CO. Iran v. Islamic Republic of Iran et al. (1989).

37 INTER-AMERICAN COURT OF HUMAN RIGHTS. Judgement of case Ximenes-Lopes v. Brazil (2006). Available in: <http:/ / www. corteidh.or.cr/docs/casos/articulos/seriec_149_ing.pdf $>$.

38 OFFICE OF THE UNITED NATIONS HIGH COMMISSIONER FOR HUMAN RIGHTS. Guiding principles on business and buman rights, 2011. Available in: < https://www.ohchr.org/Docu- bly received throughout the international community, not only by States, but also regional bodies; the General Assembly of the Organization of American States (OAS) endorsed the principles in June 2014. ${ }^{39}$ Similarly, the Maastricht Principles on Extraterritorial Obligation of States in the area of Economic, Social and Cultural Rights provide in principle 24 , with respect to the obligation to regulate, that

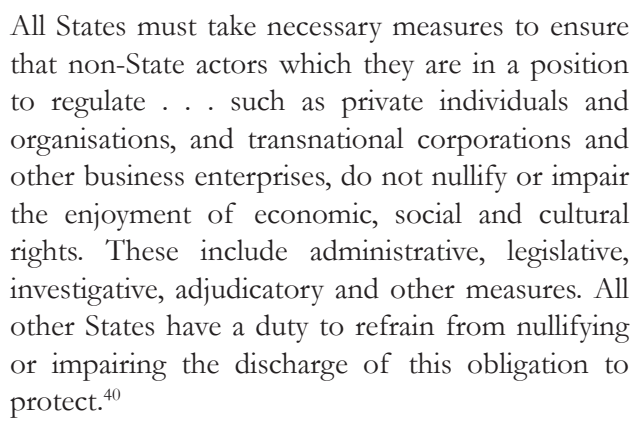

This is the present-day panorama in terms of inter-American standards on responsibility for human rights infringements committed by corporations operating in a third State. That said, on the topic of corporate responsibility for human rights violations, several initiatives have been taken since the $70 \mathrm{~s}$. This latter part will be focused on the allusion in arbitral awards to human rights abuses as a new route to make companies assume their responsibility for human rights violations related to the execution of their projects in the host States. This arbitral process practice, that is a result of the meeting of different actors and of the application of different normative sources, allows the internationalization of law or a private transnational regulation. ${ }^{41}$ As we depart from the guidelines on international responsibility that up to now exist in the inter-American human rights system, the scope of this idea seeking to reconcile human rights imperatives with trade objectives will be referred to the States Parties of the OAS. ${ }^{42}$

ments/Publications/GuidingPrinciplesBusinessHR_EN.pdf>.

39 WOODS, Cindy. Engaging the U.N: guiding principles on business and human rights: the inter-american commission on human rights \& the extractive sector, Revista de Direito Internacional, v. 12 , n. 2, p. 571-588, 2015. p. 572.

40 ETO CONSORTIUM. Maastricht principles on extraterritorial obligation of States in the area of economic, social and cultural rights. Available in: < https://www.etoconsortium.org/nc/en/ main-navigation/library/maastricht-principles/?tx_drblob_ pi1 $\% 5$ BdownloadUid $\% 5 \mathrm{D}=23>$.

41 MANGE, Flávia Foz. As características do direito transnacional como metodologia: análise sob o enfoque dos aspectos processuais da arbitragem, Revista de Direito Internacional, v. 13, n. 3, p. 126-144, 2016. p. 127.

42 Currently, all 35 independent States in the Americas have rati- 
Two paths approach companies to the observance of human rights: the corporate social responsibility and the corporate responsibility for human rights violations. The first one is a self-regulation and strategy established by the enterprises in order to improve their image and performance in social and environmental fields, for instance. The concept of responsible corporate conduct demands that companies, during their operations, observe not only national regulations, but also norms foreseen on the international and transnational legal frameworks. ${ }^{43}$ The second one refers to the direct prosecution of corporations for human rights violations committed in the execution of their projects, whether in the host country or in the State of origin, through effective judicial remedies enabling victims access to justice and reparation. On this matter, much has been achieved on the first type of responsibility, but few has progressed the second one.

Human rights abuses committed by corporations operating in States affected by social inequality and high poverty could be aggravated by judicial barriers preventing an effective judicial remedy and equal access to justice and redress. In this sense, there is a nascent trend in the civil sphere toward removing jurisdictional barriers to civil proceedings and allowing better access to justice in national courts in territories other than those where the infringement took place. That said, considering that some issues such as the extraterritorial application of human rights standards and the State duty to control activities developed by the companies constituted under its jurisdiction are still pending, some legal scholars propose to work on improving what already exists.

National courts are the first ones called to consider human rights abuses, since conducting investigations and procedures in the territory where human rights violations are committed is more feasible, reliable and simple due to the proximity of the facts and evidence that could support arguments of the parties. ${ }^{44}$ Nevertheless, one relevant problem is the impossibility of the States or lack of political will to take legal action against cor-

fied the OAS Charter.

43 ZIERO, Gabriel Webber. O conceito de conduta empresarial responsável à luz dos ordenamentos jurídicos brasileiro, internacional e transnacional, Revista de Direito Internacional, v. 13, n. 3, p. 81 94, 2016. p. 86.

44 RIVERA, Humberto Cantú. Empresas y derechos humanos: ¿hacia una regulación jurídica efectiva, o el mantenimiento del status quo?, Anuario Mexicano de Derecho Internacional, v. 13, p. 313-354, 2003. p. 341. porations being responsible for human rights abuses, all as a result to remain as an attractive place for foreign investment or due to lack of governance or effective rule of law. ${ }^{45}$

Before this situation, the considerations contained in arbitral awards related to conflicts arising from concessional agreements emerge as a solution in order to reconcile human rights imperatives with trade objectives. Even if the courts of international arbitration have as material jurisdiction interpreting investment agreements, and ruling about human rights impairments would depend on a clause granting jurisdiction, in the future, courts of international arbitration sensitive to corporate responsibility situations involving human rights could be envisaged, this from lending weight within the arbitral awards to arguments brought by the States about commitments to protect human rights, substantiating affectations to the rights of investors based on those reasons. ${ }^{46}$

The above could be possible from courts of arbitration gradually self-considered as actors in the international community, and not just as agents for resolving disputes. ${ }^{47}$ The above could also be feasible from courts that include in their arbitral awards the imperative content of Article 36 of the OAS Charter previously mentioned. To conclude, taking into account the current absence of principal legal personality of corporations as subjects of international law and, as a result, the inability of human rights systems to judge them as direct responsible for human rights infringements, also added to the impossibility or lack of political will-in some cases-of national courts to prosecute them, considerations contained within arbitral awards related to human rights disregards by corporations could be a route to reconcile human rights imperatives with trade objectives and ensure compensations for the victims.

45 RIVERA, Humberto Cantú. Empresas y derechos humanos: ¿hacia una regulación jurídica efectiva, o el mantenimiento del status quo?, Anuario Mexicano de Derecho Internacional, v. 13, p. 313-354, 2003. p. 341.

46 RIVERA, Humberto Cantú. Empresas y derechos humanos: ¿hacia una regulación jurídica efectiva, o el mantenimiento del status quo?, Anuario Mexicano de Derecho Internacional, v. 13, p. 313-354, 2003. p. 341.

47 RIVERA, Humberto Cantú. Empresas y derechos humanos: ¿hacia una regulación jurídica efectiva, o el mantenimiento del status quo?, Anuario Mexicano de Derecho Internacional, v. 13, p. 313-354, 2003. p. 341. 


\section{Conclusion}

In an era in which both the strengthening of the global market and protection of human rights are essential aims, mechanisms to render them compatible when they clash must be implemented. It is not about establishing protectionist barriers against investment agreements, conceiving them as a threat to guarding people from the risks and insecurities markets bring with them, or to reach an economic growth out of proportion without considering peoples well-being over the course. Societies must learn from the past, and past experiences have taught that living in economic isolation or dehumanization threaten the existence of societies. In addition, from the cases of certain Latin American countries, present is teaching us that market and human rights are complements in several aspects.

One could not talk about a weak governance; one could talk about collaboration between public and private sectors to manage global affairs that currently leaves behind human rights. Some point to the corporations; some others point to the North Atlantic system. Anyway, it does not have legal personality to appear before a human rights court to answer why human rights are left behind when negotiating or executing agreements. One can work on improving alternatives that already exist. One mechanism was exposed seeking to prove that human rights imperatives and trade objectives can be reconciled. In this mechanism, political will of governments is essential by making use of human rights exceptions in arbitral proceedings.

In this mechanism, human rights triumph as an exception within the execution of a set of provisions contained in agreements. Global market is a means to improve living standards, and human rights realization defines a great part of what the international community accepts as better living standards. In this sense, as several times stated before the IACHR, companies are vital actors within societies and real development must be achieved through their actions. Regarding human rights and extractive industries in Latin America, we conclude that even if international standards on responsibility of corporations and their States of origin for human rights abuses are still strengthening, positive developments represented in the extraterritorial responsibility developed by human rights bodies as well as human rights exceptions further used in arbitral proceedings, can be arising.

\section{References}

ANDRADE, Priscila Pereira de. A emergencia do direito transnacional ambiental, Revista de Direito Internacional, v. 13, n. 3, p. 18-28, 2016.

AYALA, Natalia. Derechos humanos y globalización: un análisis preliminar para América Latina. Desarrollo, Economía, Ecología y Equidad, p. 2-17, 2003.

FINNIS, John. Natural law and natural rights. Oxford: Clarendon Press, 2001.

GRANT, Andrew. Introduction and overview: the study of new regionalism(s) at the start of the second decade of the twenty-first century. In: SHAW, Timothy; GRANT, Andrew; CORNELISSEN, Scarlet. The ashgate research companion to regionalisms. Surrey: Routledge, 2012.

ETO CONSORTIUM. Maastricht principles on extraterritorial obligation of States in the area of economic, social and cultural rights. Available in: < https:// www.etoconsortium.org/nc/en/main-navigation/library/maastricht-principles/?tx_drblob_ pi1 $\% 5$ BdownloadUid $\% 5 \mathrm{D}=23>$.

HARRISON, James. Human rights and world trade agreements: using general exception clauses to protect human rights. New York: Office of the High Commissioner for Human Rights, 2005.

HAYEK, Friedrich A. Law, legislation, and liberty: a new statement of the liberal principles of justice and political economy. London: Routledge, 1976.

INTER-AMERICAN COMMISSION ON HUMAN RIGHTS. Audiencia: empresas, derechos humanos y consulta previa en América. Available in: <https:// www.youtube.com/watch? ${ }_{v}={ }_{w F q c} 7 \mathrm{ccS} 7 \mathrm{Mw}>$.

INTER-AMERICAN COMMISSION ON HUMAN RIGHTS. Audiencia: impacto de las empresas mineras canadienses sobre los derechos humanos en América Latina. Available in: <https://www.youtube.com/watc $\mathrm{h}$ ? $\mathrm{v}=\mathrm{OWYue} 8 \mathrm{FP} 9 \mathrm{ZY} \&$ feature $=$ youtu.be $>$.

INTER-AMERICAN COMMISSION ON HUMAN RIGHTS. Audiencia: situación de derechos humanos de las personas afectadas por la minería en las Américas y responsabilidad de los Estados huéspedes y de origen de las empresas mineras. Available in: <https://www. youtube $. \mathrm{com} /$ watch?v $=6 \mathrm{M} 7 \mathrm{gX} 1 \mathrm{snfCQ}>$.

INTER-AMERICAN COMMISSION ON HUMAN 
RIGHTS. Decision on request for precautionary measures of the detainees at Guantanamo Bay (2002). Available in: <http://www.oas.org/en/iachr/pdl/decisions/GuantanamoMC.asp\#MC25902>.

INTER-AMERICAN COMMISSION ON HUMAN RIGHTS. Report on admissibility no. 112/10 Franklin Guillermo Aisalla Molina (Ecuador) v. Colombia (2010). Available in: <www.cidh.org/annualrep/2010eng/EC-CO. PI-02ADM.EN.doc $>$.

INTER-AMERICAN COURT OF HUMAN RIGHTS. Judgement of case Ximenes-Lopes v. Brazil (2006). Available in: <http://www.corteidh.or.cr/docs/casos/articulos/ seriec_149_ing.pdf>.

INTERNATIONAL MONETARY FUND. La globalización: ¿amenaza u oportunidad? Available in: <https:// www.imf.org/external/np/exr/ib/2000/esl/041200s. htm>.

MANGE, Flávia Foz. As características do direito transnacional como metodologia: análise sob o enfoque dos aspectos processuais da arbitragem, Revista de Direito Internacional, v. 13, n. 3, p. 126-144, 2016.

MONEBHURRUN, Nitish. Mapping the duties of private companies in international investment law. Revista de Direito Internacional, Brasília, v. 14, n. 2, p. 50-71, 2017.

MOONHAWK, Kim. Inspecting the termites: market structure and WTO's consideration process of PTAs. American Political Science Association, 2013.

OFFICE OF THE UNITED NATIONS HIGH COMMISSIONER FOR HUMAN RIGHTS. Guiding principles on business and buman rights, 2011. Available in: <https://www.ohchr.org/Documents/Publications/ GuidingPrinciplesBusinessHR_EN.pdf>.

ORGANIZATION FOR ECONOMIC COOPERATION AND DEVELOPMENT. Trading out of poverty: how aid for trade can help. OECD Journal on Development, v. 10, n. 2, p. 7-41, 2010.

ORGANIZATION OF AMERICAN STATES. American convention on buman rights. Available in: <https:// www.cidh.oas.org/basicos/portugues/c.convencao_ americana.htm>.

ORGANIZATION OF AMERICAN STATES. Charter of the organization of American States. Available in: $<$ https://www.oas.org/dil/port/tratados_A-41_Carta_da_Organiza\%C3\%A7\%C3\%A3o_dos_Estados_ Americanos.htm>.
ORGANIZATION OF AMERICAN STATES. Additional protocol to the American Convention on Human Rights in the area of economic, social and cultural rights. Available in: $<$ http://www.cidh.org/Basicos/Portugues/e.Protocolo_de_San_Salvador.htm>.

PHILIPS PETROLEUM CO. Iran v. Islamic Republic of Iran et al. (1989).

RIVERA, Humberto Cantú. Empresas y derechos humanos: ¿hacia una regulación jurídica efectiva, o el mantenimiento del status quo?, Anuario Mexicano de Derecho Internacional, v. 13, p. 313-354, 2003.

RODRIK, Dani. The globalization paradox. New York: W. W. Norton \& Company, 2011.

SASSEN, Saskia. The State and globalization. In: HALL, Rodney Bruce; BIERSTEKER, Thomas J. (Ed.) The emergence of private authority in global governance. Cambridge: Cambridge University Press, 2002.

UNITED NATIONS. International covenant on civil and political rights. Available in: <https://www.ohchr.org/en/ professionalinterest/pages/ccpr.aspx $>$.

WALLERSTEIN, Immanuel. World systems analysis. London: Duke University Press, 2004.

WOODS, Cindy. Engaging the U.N: guiding principles on business and human rights: the inter-american commission on human rights \& the extractive sector, Revista de Direito Internacional, v. 12, n. 2, p. 571-588, 2015.

ZARRA, Giovanni. Right to regulate, margin of appreciation and proportionality: current Status in investment arbitration in light of Philip Morris v. Uruguay, Revista de Direito Internacional, v. 14, n. 2, p. 95-120, 2017.

ZIERO, Gabriel Webber. O conceito de conduta empresarial responsável à luz dos ordenamentos jurídicos brasileiro, internacional e transnacional, Revista de Direito Internacional, v. 13, n. 3, p. 81-94, 2016. 
Para publicar na Revista de Direito Internacional, acesse o endereço eletrônico www.rdi.uniceub.br ou www.brazilianjournal.org.

Observe as normas de publicação, para facilitar e agilizar o trabalho de edição. 